DEVELOPMENT OF MANAGEMENT AND ENTREPRENEURSHIP METHODS ON TRANSPORT, № 2 (71), 2020
РОЗВИТОК МЕТОДІВ

УПРАВЛІННЯ ТА ГОСПОДАРЮВАННЯ

НА ТРАНСПОРТІ, № 2 (71), 2020
УДК 656.61

JEL R 41

DOI 10.31375/2226-1915-2020-2-102-112

Ю.В. Бичковський капітан далекого плавання, аспірант ORCID 0000-0003-1459-9029

A.B. Шахов д.т.н., професор, проректор 3 навчально-організаційної роботи ORCID 0000-0003-0142-7594 avshakhov@ukr.net

Одеський національний морський університет

Одеса, Украӥна

ОЦНКА ВПЛИВУ

ЛЮДСЬКОГО ЕЛЕМЕНТУ НА БЕЗПЕКУ МОРСЬКОГО СУДНОПЛАВСТВА

Анотація. Стаття присвячена вивченню процесів управління безпекою на мор ському транспорті на основі використання міжнародних стандартів серії ICO $31000_{3}$ управління ризиками. Виходячи з трунтовного аналізу спеціальної літератури, знайила підтвердження гіпотеза про першочерговий вплив саме людського елементу на ймовірність настання аварійних ситуачій під час реалізаиії прочесів в судноплавстві. Запропоновано метод побудови матрииі ризиків, який базується на концепџї прийнятного ризику - величини, яка приймається менеджментом судноплавної компанії як компроміс між забезпеченням будьякого рівня безпеки та витратами, щьо слід понести на впровадження иього рівня. Розглянуто три основні складові людського елементу: індивідуальна, виробнича та організачійна $i$ запропоновано перелік питань, які дозволяють визначити величину людського елементу. Використання запропонованого методу дозволить, з одного боку, підвищити ефективність формування екіпажів суден, а з іншого - оптимізувати прочеси навчань і тренувань моряків впродовж рейсу.

Ключові слова: безпека судноплавства, прийнятний ризик, людський елемент, матриия ризиків.

() Бичковський Ю.В., Шахов А.В., 2020
УДК 656.61

JEL R 41

DOI 10.31375/2226-1915-2020-2-102-112

Ю.В. Бычковский капитан дальнего плавания, аспирант А.В. Шахов д.т.н., профессор, проректор по учебно-организационной работе avshakhov@ukr.net Одесский национальный морской университет Одесса, Украина

\section{ОЦЕНКА ВЛИЯНИЯ ЧЕЛОВЕЧЕСКОГО \\ ЭЛЕМЕНТА НА БЕЗОПАСНОСТЬ МОРСКОГО СУДОХОДСТВА}

Аннотация. Статья посвящена изуче нию процессов управления безопасностью на морском транспорте на основе использования международных стандартов серии ИСО 31000 по управлению рисками. Исходя из глубокого анализа специальной литературы, нашла подтверждение гипотеза о первоочередном влиянии человеческого элемента на вероятность наступления аварийных ситуаций при реализации прочессов в судоходстве. Предложен метод построения матрицы рисков, основанный на концепиии приемлемого риска - величины, принимаемой менеджментом судоходной компании как компромисс между обеспечением любого уровня безопасности и затратами, которые следует понести на внедрение этого уровня. Рассмотрень три основные составляющие человеческого элемента: индивидуальная, производственная и организационная и предложен перечень вопросов, которые позволяют определить величину человеческого элемента. Использование предложенного метода позволит, с одной стороны, повысить эффективность формирования экипажей судов, а с другой - оптимизировать процессы учений и тренировок моряков в течение рейса.

Ключевые слова: безопасность судоходства, приемлемый риск, человеческий элемент, матрииа рисков. 
UDC 656.61

JEL R 41

DOI 10.31375/2226-1915-2020-2-102-112

Yuriy Bychkovsky

Captain, graduate student

ORCID 0000-0003-1459-9029

Anatoliy Shakhov

Doctor of Technical Sciences, Professor, Vice-Rector avshakhov@ukr.net

Odessa National Maritime University, Odessa, Ukraine

\title{
ASSESSMENT OF THE IMPACT OF THE HUMAN ELEMENT ON THE SAFETY OF MARITIME SHIPPING
}

\begin{abstract}
The article is devoted to the study of safety management processes in maritime transport based on the use of international standards of the ISO 31000 series on risk management. The concept of acceptable risk is accepted as a theoretical basis of research, necessity of formation of which is caused by impossibility of creation of absolutely safe processes and faultless equipment and systems. The magnitude of acceptable risk must combine the technical, economic and social aspects of shipping. In practice, this is always a compromise between the current level of security and the possibility of improving it by various methods. Further risk reduction makes the activity itself economically impractical and forces the owner to abandon such processes. In the analysis of the risks of accidents during the implementation of maritime shipping processes, it is proposed to identify four key factors: the human element, technical, technological and external. The probability of a security incident is calculated as the sum of sets of expert values of these factors on their weight. The weight of the factors is proposed to be determined on the basis of the ranking method according to Fishburne's formula.

It is difficult to calculate the damage from an accident, as it must include the damage caused to the shipowner, crew members, cargo owners and so on. The article proposes the introduction of four levels of severity of consequences: catastrophic, critical, significant and insignificant, while the assignment of a particular incident to a particular level of consequences is determined by the method of expert assessments.

Based on a thorough analysis of the special literature, the hypothesis of the primary influence of the human element on the probability of accidents during the implementation of processes in shipping was confirmed. A method of building a risk matrix is proposed, which is based on the concept of acceptable risk - a value that is accepted by the management of the shipping company as a compromise between ensuring any level of safety and the costs to be incurred for the implementation of this level. Three main components of the human element are considered: individual, production and organizational and a list of questions is proposed to determine the size of the human element. The use of the proposed method will, on the one hand, increase the efficiency of the formation of ship's crews, and on the other - to optimize the processes of training and coaching of seafarers during the voyage.
\end{abstract}

Keywords: shipping safety, acceptable risk, human element, risk matrix. 
Постановка проблеми. Незважаючи на впровадження в практику судноплавства найпередовіших досягнень науки і техніки, використання при будівництві та обладнанні суден новітніх технологій, щорічно в морі відбуваються трагедії, десятки суден тонуть, горять, вибухають, нарешті просто безслідно зникають - гинуть сотні людей, втрачаються сотні тонн вантажів. Судна працюють у ворожому природному середовищу (шторми, льоди, тумани, течії), на них встановлено багато складних конструктивних елементів, пристроїв і приладів, які можуть відмовити з різних причин, норми і правила, що регламентують управління суднами i їх експлуатацію, недосконалі і мають недоліки. Але найголовніше обставина - на суднах працюють люди, здатні робити необдумані вчинки i дії, допускати помилки і промахи, не завжди достатньо компетентні i дисципліновані. Оскільки саме людський фактор вважається головним чинником переважної більшості інцидентів безпеки на флоті (до $75 \%$ ), в прагненні підвищити безпеку мореплавання Міжнародна Морська Організація (IMO) зосередила увагу на людях, які працюють на флоті, від яких безпека головним чином і залежить [1].

Однак, запропоновані IMO piшення, нажаль, не призвели до бажаних практичних результатів: загальна кількість аварій майже не зменшується, а економічні наслідки від них з кожним роком зростають. Методологічною базою досліджень галузі безпеки судноплавства прийнята теорія управління ризиками, що не викликає сумнівів. А ось стосовно моделей, методів оцінки ризиків та конкретних інструментів управління безпекою - єдиних науково обгрунтованих підходів досі не знайдено.

Огляд останніх досліджень та літератури. На початку XX століття багато дослідників починають звертати увагу на взаємозв'язок між «людиною і виробництвом». Так, англійський економіст Бенджамін Сіб, в своїй книзі «Людський фактор в підприємництві» [2] виданої в 1921 році, запустив в життя термін «людський фактор». Вперше про «людську помилку» людство заговорило після 1931, коли дане поняття було описано видатним американським вченим Хербертом Вілліамом Хенрічем [3]. У своїй роботі він проаналізував причини тисяч актів-розслідувань нещасних випадків на виробництві та сформулював термін «людська помилка». 3 тих пір, при розслідуванні будь-яких пригод, аварій на виробництві, термін «людська помилка» стає базисним або основним в переліку всіх можливих причин нещасних випадків. У загальному випадку, цей термін означає, що, щось було зроблено, що «не призначене для суб'єкта; небажано для набору правил або зовнішнього спостерігача; або вивело завдання або систему за допустимі межі». Іншими словами, це відхилення від наміру, очікування або бажаності.

Подальше свій розвиток даний феномен отримав в роботі Г. Петерсен і А. Хассмана, виданої в 1959 році [4]. У цій роботі було дано детальне пояснення терміну «людський фактор». Г. Петерсен описав цей фактор 3 трьох боків:

- теоретичного - людський фактор позначає будь-яке значне відхилення від встановленого стандарту людської діяльності; 
DEVELOPMENT OF MANAGEMENT AND ENTREPRENEURSHIP METHODS ON TRANSPORT, № 2 (71), 2020
РОЗВИТОК МЕТОДІВ

УПРАВЛІННЯ ТА ГОСПОДАРЮВАННЯ

НА ТРАНСПОРТІ, № 2 (71), 2020
- практичного - термін може мати будь-який 3 кількох конкретних значень, в залежності від характеру вимог, конкретної програми, звичайних процедур класифікації помилок ... i емоційних конотацій, пов'язаних 3 використанням терміну, який може бути помилково сприймається як можливе покладання провини на окремих осіб або їх безпосереднє спостереження.

- у реальній ситуації, коли аргументи про те, що є або не є людською помилкою, мають менше значення, ніж те, що можна зробити, щоб їм запобігти.

Термін «людський фактор» у порівнянні 3 терміном «людська помилка» - це більш нейтральна фраза, яка може мати кілька значень в залежності від області, до якої вона відноситься. Даний термін може бути використаний в якості дисципліни під назвою «ергономіка»; таким чином, це означає «наукове дослідження людини в його робочому середовищі». В іншому випадку - це може означати «людську інженерію», коли мова йде про людино-машинному інтерфейсі в застосуванні комп'ютерів. У контексті безпеки морських систем «людський фактор» охоплює «широкий спектр елементів, залучених у взаємодію між людьми i їх робочим середовищем» (Feyer \& William) [5].

Термін «людський фактор» означає: «... сприйняття, розумові та фізичні можливості людей і взаємодія людей 3 роботою і робочим середовищем, вплив конструкції обладнання i систем на продуктивність людини i, перш за все, організаційні характеристики, які впливають на безпеку, пов'язану поведінкою на роботі» (UK Health and Safety Executive) [6].
С інші визначення даного терміну. Наприклад, «людський фактор» - це фізична або когнітивне властивість індивідуума або соціальна поведінка, характерна для людини, яка може впливати на функціонування соціотехнічних систем.

Даний термін набув широкого поширення в світі і якийсь час був офіційно визнаний IMO при визначенні причин аварій та подій 3 морськими суднами під час розслідування нещасних випадків на морі. Однак, в 90-х роках IMO стала використовувати термін «людський елемент». Основоположним базисом в даній області стала Резолюція IMO А.884 (21) від 1999 року [7].

За визначенням IMO, озвученому в Резолюції А.947 (23), «людський елемент» - це складна багатогранна проблема, яка впливає на безпеку на морі, охорону і захист морського середовища. Він включає в себе весь спектр людської діяльності, виконуваної екіпажами суден, береговим керівництвом, регулюючими органами, визнаними організаціями, верфями, законодавцями та іншими відповідними сторонами, які повинні ефективно співпрацювати для вирішення проблем людського елемента [8].

Сьогодні склалася ситуація, коли багато працівників морської галузі, на наш погляд, не розуміють повного сенсу вимовлених термінів, що завдає певної шкоди будь-яким діям, спрямованим на докорінну зміну ситуації, пов'язаної з безпекою в морській галузі. Аналізуючи більш 100 різних публікацій 3 даної тематики, я звернув увагу, що багато дослідників одні і ті ж обставини відносили до людського фактора або до 
людського елементу. Для поліпшення ситуації, необхідно дотримуватися смислових формулювань даних термінів. Звідси випливає наступне:

- коли ми говоримо про «людської помилку», то повинні чітко уявляти собі наявність результату, який відрізняється від бажаного;

- коли ми говоримо про «людський фактор», то це означає що ми розглядаємо процес взаємодії «людина-робоче середовище»;

- коли ми говоримо про «людський елемент», то ми говоримо про багатогранну систему, націлену на підвищення безпеки мореплавства, охорони i захисту навколишнього середовища.

В якості методології системи управління безпекою судноплавства IMO, по аналогії з багатьма установами і організаціями, обрана теорія ризик-менеджменту [9]. За останні роки розроблені десятки настанов, керівництв, методик визначення ризиків, як на рівні IMO, так і окремих держав та судноплавних компаній. Однак, ефективних результатів цієї діяльності поки ще не досягнуто. На нашу думку, це пов'язано з відсутністю чіткої науково-обгрунтованої моделі визначення ризиків та аналізу впливу людського елементу на їх величину.

Метою завдання даного дослідження $\epsilon$ розробка методу визначення людського фактора ризику виникнення АС в торговельному судноплавстві і аналізу заходів, націлених на зменшення його складових.

Основний матеріал дослідження. Серед десятків різних дефініцій ризику зупинимось на такому: ризик - кількісна характеристика ймовірності виникнення аварійної ситуації, пов'язаної 3 виробничим процесом, 3 урахуванням збитків від iii настання $[10 ; 11]$.

3 даного визначення слід відмітити, що ризик:

- обумовлений виробничою діяльністю $\mathrm{i} \epsilon$ характеристикою процесу;

- носить потенційний характер;

- розраховується як економічна категорія.

У загальному випадку рівень ризику $\mathrm{R}$ визначається за допомогою двох величин - ймовірності настання аварійної ситуації $\mathrm{P}$ та збитків від іiї наслідків C

$$
\boldsymbol{R}=\boldsymbol{P} \cdot \boldsymbol{C} .
$$

Відомо, що традиційний підхід до безпеки базується на категоричному імперативі: забезпечити «абсолютну» безпеку, не допустити ніяких аварій. Як показує практика, така концепція не адекватна реальній ситуації. Сучасний світ відкинув концепцію «абсолютної» безпеки, зважаючи на неможливість іiї досягнення, i прийшов до концепції прийнятного (допустимого) ризику [38-40].

Необхідність формування концепції прийнятного ризику обумовлена неможливістю створення абсолютно безпечних процесів та безвідмовних обладнання і систем. Величина прийнятного ризику повинна поєднувати в собі технічні, економічні і соціальні аспекти судноплавства. На практиці це завжди компроміс між діючим рівнем безпеки та можливостями його підвищення різними методами. Подальше зменшення ризику робить економічно недоцільною саму діяльність і примушує власника від- 
мовитись від реалізації таких процесів.

Визначимо прийнятний ризик аварійної ситуації як максимальну величину ризику, яка доцільна за технічними, економічними і технологічними можливостями для даного судна [12]. Плануючи будь-яку операцію, особа, що приймає рішення, повинна визначити ризик, порівняти його 3 прийнятним і зробити висновок про ii допустимість $з$ позиції забезпечення встановленого рівня безпеки.

Міжнародний стандарт з ризикменеджменту ICO 31010 визначає десятки різних методів оцінки ризиків [10]. Однак жодний 3 них не дає задовільного результату при вирішенні задачі впливу саме людського фактора на безпеку процесів торговельного судноплавства.

У роботі [13] розглядається чотири фактори небезпеки виникнення аварійної ситуації в ході реалізації виробничого процесу:

- технічний;

- технологічний;

- людський елемент;

- зовнішній.

Інтегральний показник чинників небезпеки характеризує ступінь впливу всіх факторів небезпеки на виникнення аварійної ситуації (АC).

Найбільш ймовірне значення інтегрального показника впливу всіх факторів небезпеки на виникнення АC може бути представлено у вигляді середнього зваженого значення 3 показників аналізованих факторів даної ситуації

$$
F=\sum_{i=1}^{n} F_{i} \cdot w_{i},
$$

де $\mathrm{F}_{\mathrm{i}}$ - ступінь ймовірності виникнення АC по і-му фактору;

$\mathrm{w}_{\mathrm{i}}$ - вагомість і-го фактора;

$\mathrm{n}$ - число факторів.

Для випадку чотирьох факторів небезпеки формула приймає вигляд

$$
\mathrm{F}=\mathrm{F}_{1} \cdot \mathrm{w}_{1}+\mathrm{F}_{2} \cdot \mathrm{w}_{2}+\mathrm{F}_{3} \cdot \mathrm{w}_{3}+\mathrm{F}_{4} \cdot \mathrm{w}_{4}
$$

Вагомості $\mathrm{w}_{\mathrm{ni}}$ параметрів, як правило, розраховуються за допомогою методу простого ранжування, пропорційного методу або методу попарного порівняння. Якщо існує можливість проранжувати всі параметри n-го фактора в порядку убування їх значущості $\left(\mathrm{w}_{\mathrm{n} 1}>\mathrm{w}_{\mathrm{n} 2}>\cdots>\mathrm{w}_{\mathrm{nN}}\right)$, то вагомість i-го параметра можна визначити за правилом Фішберна

$$
w_{n i}=\frac{2(N-i+1)}{N(N+1)},
$$

де $N$ - число параметрів даного фактора.

Якщо врахувати при цьому статистику причин виникнення аварійних ситуацій в торговельному судноплавстві, розподіл вагових коефіцієнтів різних факторів небезпеки складе:

- людський елемент - 0,4;

- технічний фактор - 0,3;

- зовнішній фактор - 0,2;

- технологічний фактор - 0,1.

На підставі розрахунку величини $F$ визначимо ймовірність настання $\mathrm{AC}$ за таким правилом:

- мала, якщо $0<\mathrm{F}<=0,25$;

- середня, якщо $0,25<\mathrm{F}<=0,5$;

- велика, якщо $0,5<\mathrm{F}<=0,75$;

- небезпечна, якщо $\mathrm{F}>=0,75$.

Розрахунок збитків від АС виконати досить важно, оскільки вони повинні містити шкоду, заподіяну i судновласнику, i членам екіпажу, i вантажовласникам тощо. Нами про- 
понується введення чотирьох рівнів важкості наслідків АС (табл. 1), при цьому віднесення конкретного інциденту до того чи іншого рівня наслідків визначається методом експертних оцінок.
Типова форма матриці ризиків, що містить 4 рівні частот і 4 рівні тяжкості наслідків, в якій загальний рівень ризику ранжується за 4-ма категоріями, наведена на рис. 1.

Типові рівні важкості наслідків подій

Таблиия 1

\begin{tabular}{|c|l|}
\hline $\begin{array}{c}\text { Рівні важкості } \\
\text { наслідків подій }\end{array}$ & \multicolumn{1}{|c|}{ Наслідки за видами ризиків } \\
\hline Катастрофічний & $\begin{array}{l}\text { Загибель хоча б 1 людини, або втрата судна, або збитки для } \\
\text { навколишнього середовища, які призводять до стану екологі- } \\
\text { чної катастрофи }\end{array}$ \\
\hline Критичний & $\begin{array}{l}\text { Тяжкі тілесні ушкодження, або значні втрати вантажу, або } \\
\text { сутєві екологічні наслідки }\end{array}$ \\
\hline Істотний & $\begin{array}{l}\text { Шкода здоров’ю середньої важкості, або пошкодження суд- } \\
\text { на, що потребує проведення аварійного ремонту або шкода } \\
\text { для навколишнього середовища, яка викликає надзвичайну } \\
\text { ситуацію локального характеру }\end{array}$ \\
\hline Незначний & $\begin{array}{l}\text { Пошкодження окремих елементів судна чи частково вантажу, } \\
\text { або незначна шкода для навколишнього середовища }\end{array}$ \\
\hline
\end{tabular}

Джерело: розроблено авторами

\begin{tabular}{|l|l|l|l|l|}
\hline \multirow{2}{*}{ Ймовірність } & \multicolumn{4}{|c|}{ Важкість наслідків (потенціальна шкода) } \\
\cline { 2 - 5 } & \multicolumn{1}{|c|}{ Незначна } & \multicolumn{1}{|c|}{ Істотна } & \multicolumn{1}{|c|}{ Критична } & Катастрофічна \\
\hline Мала & Прийнятний & Прийнятний & Надмірний & Надмірний \\
\hline Середня & Прийнятний & Надмірний & Надмірний & Неприйнятний \\
\hline Велика & Прийнятний & Надмірний & Неприйнятний & Неприйнятний \\
\hline Небезпечна & Надмірний & Неприйнятний & Неприйнятний & Неприйнятний \\
\hline
\end{tabular}

Рис. 1. Матриия ризиків виникнення АС та їх наслідків

Таким чином, кожній несприятливій події буде відповідати пара якісних значень за шкалами ймовірності і наслідків, що дозволяє віднести цю подію до певної клітини матриці ризику. Найскладнішим i відповідальним при побудові мат- риці ризику є процес призначення рівня прийнятного ризику аварійної ситуації. При цьому необхідно врахувати, що прийнятний ризик - динамічна категорія, що має множинну предметність в залежності від конкретної області застосування. 
Оцінка рівня прийнятного ризику АС завжди відносна. Спроби безпосередньо прописати цій оцінці чисельне значення безперспективні в плані подальшої інтерпретації результатів. Рівень прийнятного ризику АС не існує сам по собі, у відриві від конкретного технологічного процесу і конкретного об'єкта. Саме тому поняття прийнятності ризику має не тільки об'єктивну, але й суб'єктивну сторону, оскільки оцінка його рівня проводиться в кінцевому підсумку експертом.

Проаналізуємо формулу (1). Значення технічного, технологічного та зовнішнього факторів ймовірності настання інцидентів безпеки не складно визначити методом експертних оцінок на підставі аналізу фактичного стану обладнання, результатів технічного діагностування, даних прогнозу погодних умов тощо.
Найбільшу складність викликає визначення людського елементу та розробка заходів керування цим параметром.

Такий підхід дозволить врахувати при оцінці ризиків результати досліджень багатьох дослідників, згідно 3 якими саме людський елемент є основним фактором виникнення АС. Однак для зменшення цієї складової і загального ризику необхідно більш детально проаналізувати джерела і методи оцінки саме людського фактора ризиків безпеки судноплавства.

Аналіз значної кількості публікацій, присвячених вивченню причин виникнення $\mathrm{AC}$ на суднах дозволив визначити основні чинники, які впливають на рівень безпеки. У таблиці 2 наведено відсоток згадок про ту чи іншу причину в іноземних та вітчизняних публікаціях.

Таблиия 2

Аналіз причин виникнення АС на суднах

\begin{tabular}{|c|l|c|}
\hline Номер з/п & \multicolumn{1}{|c|}{ Фактор } & $\begin{array}{c}\text { Відсоток згадок фактора } \\
\text { у публікаціях, } \%\end{array}$ \\
\hline 1 & Втома & 72,2 \\
\hline 2 & Стрес & 65,6 \\
\hline 3 & Відсутність взаєморозуміння & 46,7 \\
\hline 4 & Нестача знань & 36,7 \\
\hline 5 & Нестача досвіду & 33,3 \\
\hline 6 & Стан здоров'я & 26,7 \\
\hline
\end{tabular}

Джерело: розраховано авторами

Багато дослідників, розглядаючи людський феномен, поділяють його на цілий ряд окремих блоків. Так, вони називають ці блоки порізному, але якщо взяти цей принцип за основу, то можна легко уявити собі загальну структурну схему даного феномена. На нашу думку, в поняття «людський елемент» повинні входити сукупність складових (блоків), що включає, але не обмежується наступним: 
- індивідуальна складова:

- рівень підготовки;

- досвід;

- психофізіологічні особливості

поведінки;

- стан здоров'я;

- виробнича (ергономічна) складова:

- дизайн судна, обладнання, робочого місця;

- організація побуту і відпочинку на судні;

- умови роботи і проживання на борту судна;

- організаційна складова:

- технологія виконання суднових робіт;

- належна система планування i керівництва роботами;

- стан системи управління на борту судна і в компанії.

Якщо оцінити кожну з десяти наведених складових від 0 до 0,1 балів, отримаємо значення фактору «людський елемент» для члена екіпажу $\mathrm{F}_{\text {л }}$ в діапазоні 0-1. При цьому, якщо $\mathrm{F}_{\text {л }}=1$, такий фахівець здатен забезпечити виконання функцій, обумовлених його посадою, 3 мінімальною ймовірністю виникнення АС.

Використання запропонованого методу дозволить, з одного боку, під- вищити ефективність формування екіпажів суден, а 3 іншого - оптимізувати процеси навчань і тренувань моряків впродовж рейсу.

\section{Висновки.}

1. На підставі аналізу значного обсягу літературних джерел підтверджено визначний вплив людського фактора на підтримку належного рівня безпеки в торговельному судноплавстві.

2. Запропоновано використання терміну «людський елемент», який містить в собі весь спектр людської діяльності, виконуваної екіпажами суден, береговим керівництвом, регулюючими органами, визнаними організаціями, верфями, законодавцями та іншими відповідними сторонами, які повинні ефективно співпрацювати для вирішення проблем безпеки мореплавання.

3. Розроблено метод побудови матриці ризиків процесів судноплавства, який базується на методології управління ризиками та відповідає вимогам стандартів ICO серії 31000 .

4. Виконано грунтовний аналіз факторів, що визначають величину людського елементу, яка містить індивідуальну, виробничу та соціальну складові.

\section{СПИСОК ЛІТЕРАТУРИ}

1. Шахов А.В., Крамской С.А. Формирование экипажса судна на основании имитачионного моделирования // Восточно-европейский журнал передовых технологий. Харьков. № 1/5(49). 2011. С.69-70.

2. Alert G. (2010). The International Maritime Human Element Bulletin. Issue No. 22 January 2010. ISSN 1747-5015. www.he-alert.org

3. Ballard Gordon (2017) «Safety: it's all about us-the human factors behind the statistics». https://www.spe.org/en/print-article/?art $=3216$

4. Feyer Anne-Marie and Williamson Ann (1998) «Occupational injury: risk, prevention and intervention». London: Taylor \& Francis, $302 \mathrm{p}$. 
5. Harvey Catherine, Stanton Neville, Zheng Pengjun (2013). Safety at sea: human factors aboard ship. Transportation research group, faculty of engineering and environment, University of Southampton.

6. Heinrich Herbert William (1931). Industrial accident prevention: a scientific approach. McGraw-Hill book Company, Incorporated.

7. International Maritime Organization (1999). IMO Resolution A.884(21) - 25 November 1999 «Amendments to the Code for the investigation of marine casualties and incidents».

8. International Maritime Organization (2003). IMO Resolution A.947(23) Adopted on 27 November 2003 «Human element vision, principles and goals for the organization».

9. Koester Thomas (2007) «Terminology work in maritime human factors». Frydenlund Publishers Hyskenstrcede 10 DK-1207 København K Denmark frydenlund@frydenlund.dkwww.frydenlund.dk ISBN 978-87-7887-562-4.

10. Стандарт ИСО 31000. Управление рисками руководство. URL: https:// pqm-online.com/assets/files/pubs/translations/std/iso-31000-2018-(rus).pdf

11. Руденко Е.С., Шахов А.В. Програмно-иільове управління безпекою функціонування морських портів // Матеріали IX міжнародної науковопрактичної конференції «Управління проектами: стан та перспективи» M.: НУК, 2013. C.278-280.

12. Fesenko T., Shakhov A., Fesenko G. Modeling of maturity of gender-oriented project management office. Eastern-European Journal of Interiorise Technologies. 2017. Vol. 5, № 3(89). P. 30- 38. doi: 10.15587/1729-4061.2017.110286.

13. Руденко Е.С. Выбор критериев при ранжировании проектов повышения безопасности объектов портовой инфраструктуры // Матеріали X міжнародної науково-практичної конференції «Управління проектами стан та перспективи» М.: НУК, 2014. С.247-249.

\section{REFERENCES}

1. Shakhov, A.V. \& Kramskoi, S.A. (2011). Formyrovanye эkypazha sudna na osnovanyy ymytatsyonnoho modelyrovanyia [The formation of the crew on the basis of simulation]. Vostochno-evropeiskyi zhurnal peredovikh tekhnolohyi East European Journal of Advanced Technology. № 1/5(49), 69-70 [in Russian].

2. Alert G. (2010). The International Maritime Human Element Bulletin. Issue No. 22 January 2010. Retrieved from www.he-alert.org [in English]

3. Ballard Gordon (2017). Safety: its all about us-the human factors behind the statistics. Retrieved from https://www.spe.org/en/print-article/?art=3216

4. Feyer Anne-Marie and Williamson Ann (1998). Occupational injury: risk, prevention and intervention. London: Taylor \& Francis, 302.

5. Harvey Catherine, Stanton Neville, Zheng Pengjun (2013). Safety at sea: human factors aboard ship. Transportation research group, faculty of engineering and environment, University of Southampton 
6. Heinrich Herbert William (1931). Industrial accident prevention: a scientific approach. McGraw-Hill book Company, Incorporated.

7. International Maritime Organization (1999). IMO Resolution A.884(21) - 25 November 1999 "Amendments to the Code for the investigation of marine casualties and incidents».

8. International Maritime Organization (2003). IMO Resolution A.947(23) Adopted on 27 November 2003 «Human element vision, principles and goals for the organization».

9. Koester Thomas (2007). Terminology work in maritime human factors. Frydenlund Publishers Hyskenstrcede 10 DK-1207 København K Denmark frydenlund@frydenlund.dkwww.frydenlund.dk ISBN 978-87-7887-562-4.

10. Standart YSO 31000. Upravlenye ryskamy rukovodstvo. Retruived from https://pqm-online.com/assets/files/pubs/translations/std/iso-31000-2018-(rus). pdf [in Russian]

11. Rudenko E.S. \& Shakhov A.V. (2013). Prohramno-tsilove upravlinnia bezpekoiu funktsionuvannia morskykh portiv [Program-targeted management of seaport security]. Materialy IKh mizhnarodnoi naukovo-praktychnoi konferentsii «Upravlinnia proektamy stan ta perspektyvy». M.: NUK, 278-280 [in Ukrainian].

12. Fesenko, T., Shakhov, A. \& Fesenko, G. (2017). Modeling of maturity of gender-oriented project management office. Eastern-European Journal of Interiorise Technologies. Vol. 5, № 3(89), 30-38. doi: 10.15587/17294061.2017.110286 [in English].

13. Rudenko, E.S. (2014). Vibor kryteryev pry ranzhyrovanyy proektov povblshenyia bezopasnosty ob'ektov portovoi ynfrastrukturi [Selection of criteria for ranking projects to improve the security of port infrastructure facilities]. Materialy Kh mizhnarodnoi naukovo-praktychnoi konferentsii «Upravlinnia proektamy stan ta perspektyvy». M.: NUK, 2014, 247-249 [in Russian].

Стаття надійшла до редакиії 14.04.2020

Посилання на статтю: Бичковський Ю.В., Шахов А.В. Оцінка впливу людського елементу на безпеку морського судноплавства // Розвиток методів управління та господарювання на транспорті: Зб. наук. праць, 2020. № 2 (71). C. 128-139. DOI 10.31375/2226-19152020-2-102-112.

Article received 14.04.2020

Reference a JournalArtic: Bychkovsky, Yuriy \& Shakhov, Anatoliy/ (2020). Assessment of the impact of the human element on the safety of maritime shipping. Deve-lopment of management and entrepreneurship methods on transport. 2 (71), 102-112. DOI 10.31375/22261915-2020-2-102-112. 